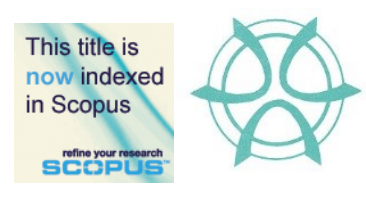

PLANNING MALAYSIA:

Journal of the Malaysian Institute of Planners

VOLUME 19 ISSUE 3 (2021), Page 295 - 306

\title{
AGRIBUSINESS AS THE SOLUTION FOR THE UNDERUTILIZED WAQF LANDS: A VIEWPOINT FROM THE WAQF ADMINISTRATORS
}

\author{
Norfaridah Ali Azizan ${ }^{1}$, Amirul Afif Muhamat ${ }^{2}$, Sharifah Faigah Syed Alwi ${ }^{3}$, \\ Husniyati Ali ${ }^{4}$, Mohamad Nizam Jaafar ${ }^{5}$ \& Nur Hidayah Jusoh ${ }^{6}$ \\ ${ }^{1,2,4}$ Faculty of Business and Management, \\ UNIVERSITI TEKNOLOGI MARA \\ ${ }^{3,5}$ Arshad Ayub Graduate Business School, \\ UNIVERSITI TEKNOLOGI MARA \\ ${ }^{6}$ Consumer Operations Department No.80, \\ AFFIN BANK BERHAD
}

\begin{abstract}
Waqf land bank in Malaysia has huge potential to be developed but most of the lands are underutilized due to the administrative and legal (conventional and Shariah) issues that are plaguing them. The underutilized land size is estimated to be around $87 \%$ from the 30,000 hectares waqf lands, as at 2018 . This study focuses on Selangor and Perak to explore on the same issue by interviewing the relevant key informants to gather their feedback. In order to unlock the potential of these waqf lands, pragmatic model or approach needs to be researched and implemented - and this study suggests agribusiness. Therefore, this study embarks on the preliminary field work that intends to assess the potential to develop the waqf lands in Selangor and Perak for agribusiness activities.
\end{abstract}

Keywords: waqf, agribusiness, lands, agriculture, model, wakaf, wakap

2 Associate Professor Dr Amirul Afif Muhamat (amirulafif@uitm.edu.my) 
Norfaridah Ali Azizan, Amirul Afif Muhamat, Sharifah Faigah Syed Alwi, Husniyati Ali, Mohamad Nizam Jaafar \& Nur Hidayah Jusoh

Agribusiness As the Solution for The Underutilized Waqf Lands: A Viewpoint from The Waqf Administrators

\section{INTRODUCTION}

The underutilized waqf lands is a continuous debatable issue that has been discussed by several parties in various platforms such as seminars, workshops, conferences and even in the parliament. We need to be fair when discussing on this issue because over the years a lot of improvements in forms of projects and activities being addressed towards the waqf lands. Nevertheless, the underutilised land size which is estimated to be around 26,100 hectares as at 2018 or $87 \%$ from the 30,000 hectares waqf lands (Kamarudin, 2019) requires immediate attention from the stakeholders.

Therefore, this study discusses on this issue by exploring the perspective of the waqf administrator, the trustees which is the state Islamic religious council. This study believes agribusiness as the pragmatic solution that can be considered for the underutilized waqf lands.

The structure of this article is as follows: literature review section to discuss on the contemporary and important studies in the area, followed by methodology (it is important to highlight that this article is an excerpt from a large scale study, therefore, only several key informants who are being included in this article as per the objective of the paper - to present the waqf administrators' views on agribusiness). The next section is findings from the key informants and last but not least is conclusion.

\section{LITERATURE REVIEW}

\section{Waqf Land Issues}

Waqf can be segregated into two categories: waqf am (general endowment) and waqf khas (specific endowment) (Abdul Karim, 2010). These types of waqf are based on the intention of endower when the person endowed a particular asset.

Likewise, these two waqf categories share similar problems which are the waqf lands are not strategically located (Muhamat \& Jaafar, 2012), lack of funds to develop the waqf land (Azmi, Hanif, \& Mahamood, 2017; Mahamood $\&$ Ab Rahman, 2015), most of the waqf lands are small in term of size as per bequest (A. Ibrahim \& Ibrahim, 2018) and in Malaysia, the administrative of the waqf lands are governed by various state religious councils (Ismail, Salim, \& Hanafiah, 2015; Rashid, Fauzi, \& Hasan, 2018).

In the context of waqf lands, one of the pragmatic approach to develop the waqf lands for productive purposes is by implementing istibdal. Despite this approach, as reported in the previous section, $87 \%$ of waqf lands are still underutilized all over Malaysia. It is not a surprise because Muhamat \& Jaafar (2012) have informed that most of the lands in the country are scattered and predominantly at the remote area.

This situation suggests that for the waqf lands that are in the remote area, most of the lands, in general, are suitable for agriculture. Furthermore, the 
individual size of the waqf lands which are small caused the waqf lands to be less attractive for commercial or residential projects. This study covers waqf lands in Selangor and Perak, specifically on the waqf lands that have potential to be used for agribusiness activities. The two state Islamic religious councils have different structure which also denote that they are governed by two different states' enactments and under the purview of the sultan in each state.

In the context of Selangor, Perbadanan Wakaf Selangor (PWS) or Selangor Waqf Incorporated (Abu Bakar, Md Hussain, \& Hamed, 2017) was established in 2011, a subsidiary of the state religious council of Selangor. This "metamorphosis" of the PWS has injected the element of corporation into the agency that is signified from the structure of PWS. The board members of PWS includes technocrats who are businessmen and experts in their fields such as architect, state director of land and mines as well as auditor.

The development of waqf lands in Selangor (as depicted in the website) is focused on residential and commercial building such as shop houses at Jalan Kebun in Klang, and it seems that less attention was given to the agribusiness activities. Table 1 shows the size of waqf lands in Selangor as at 2016 according to the districts.

Table 1: Total of waqf lands in Selangor (as at 2016)

\begin{tabular}{|l|c|c|}
\hline \multirow{2}{*}{ District } & \multicolumn{2}{|c|}{ Registered $\boldsymbol{W a q f}$ Lands } \\
\cline { 2 - 3 } & Total Lot & Size (acres) \\
\hline Klang & 216 & 203.39 \\
\hline Kuala Selangor & 184 & 210.47 \\
\hline Sabak Bernam & 312 & 412.17 \\
\hline Petaling & 65 & 24.25 \\
\hline Gombak & 90 & 50.79 \\
\hline Kuala Langat & 171 & 169.04 \\
\hline Hulu Selangor & 50 & 58.48 \\
\hline Hulu Langat & 103 & 151.80 \\
\hline Sepang & 69 & 81.79 \\
\hline Others & 8 & 10.45 \\
\hline \multirow{2}{*}{ TOTAL } & $\mathbf{1 2 6 8}$ & $\mathbf{1 3 7 2 . 6 3}$ \\
\hline
\end{tabular}

Source: http://www.wakafselangor.gov.my/index.php/hartanah-wakaf/statistik-hartanah-wakaf

In Perak, the waqf activities are managed by the Islamic religious council of Perak under the department which is known as Bahagian Pengurusan dan Pembangunan Mal dan Wakaf (BMW) to oversee and lead the waqf agenda (Abu Bakar, Md. Hussain, \& Hamed, 2017). Diagram 1 depicts the number of waqf land lot in Perak according to the districts in the state. The highest number of lots is in the 
Norfaridah Ali Azizan, Amirul Afif Muhamat, Sharifah Faigah Syed Alwi, Husniyati Ali, Mohamad Nizam Jaafar \& Nur Hidayah Jusoh

Agribusiness As the Solution for The Underutilized Waqf Lands: A Viewpoint from The Waqf Administrators

district of Kinta followed by Kuala Kangsar and Larut Matang. These three districts are well-known with agriculture produce in fact whole of Perak is blessed with fertile lands. Total is 3,591 lots of waqf lands (as per the year of research by A. Ibrahim \& Ibrahim (2018).

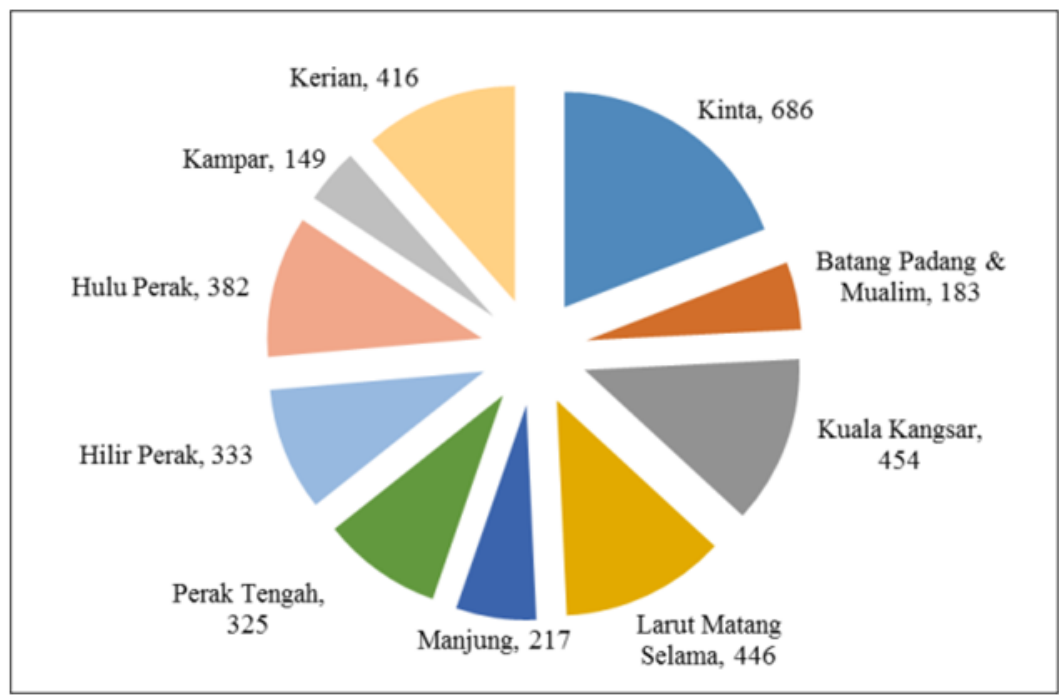

Figure 1: Number of waqf lot in Perak Source: A. Ibrahim and Ibrahim (2018)

Perak has about 3,591 lots of waqf lands that represent a size of 6,483.75 hectares (A. Ibrahim and Ibrahim, 2018). These waqf lands can be divided into five primary purposes:

Table 2: The use of waqf lands in Perak

\begin{tabular}{|l|l|}
\hline Purpose & Size (hectares) \\
\hline Mosque & 963.5 \\
\hline Musolla & 789.25 \\
\hline Islamic religious school (madrasah) & 675 \\
\hline Cemetery & 827 \\
\hline General & 3,229 \\
\hline Total & $\mathbf{6 , 4 8 3 . 7 5}$ \\
\hline & Source: A. Ibrahim and Ibrahim (2018) \\
\hline
\end{tabular}

\section{Agribusiness}

Agribusiness represents the holistic process of agriculture encompasses upstream, mid-stream and downstream process of the economic activity (Clay \& Feeney, 2019; Giraldo, 2019). Regardless the status of the countries; whether 
developed, developing or poor, this sector is pertinent due to the foods security reason as well as potential income to the countries (Behzadi, O'Sullivan, Olsen, \& Zhang, 2018).

Diagram 2 exhibits the value chain that commonly exists in agribusiness sector which are five: production, processing and aggregation, storage and distribution, marketing and consumption and lastly is after-sales service.

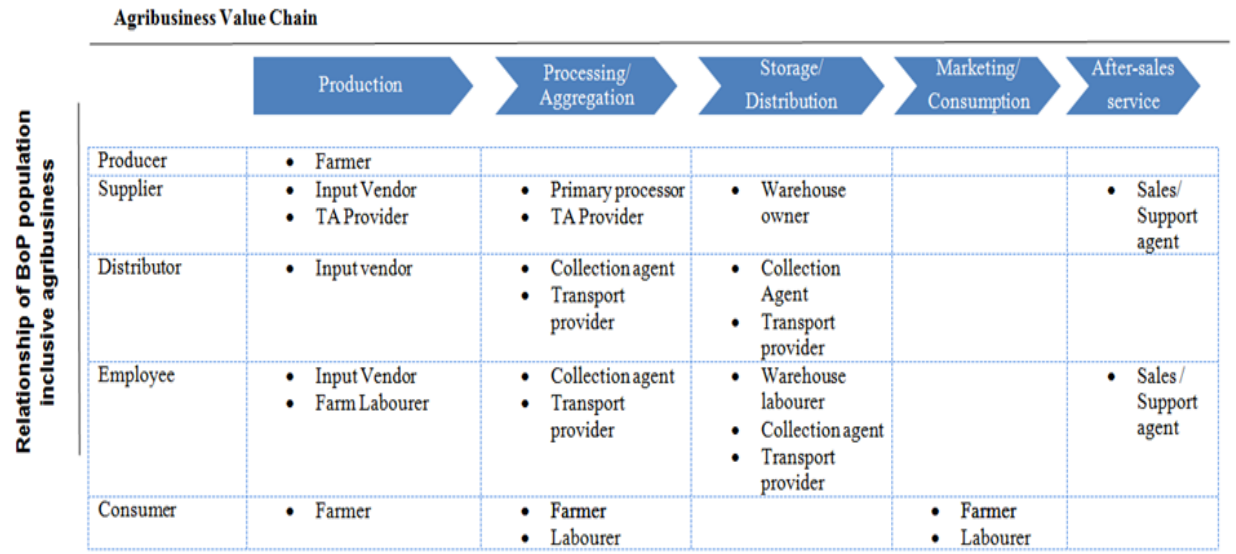

Figure 2: Agribusiness value chain from Jamal (2019)

Agribusiness is a sector that is prone to risks, thus, the value chain is subject to environment uncertainty (Yanes-Estévez, Ramón Oreja-Rodríguez, \& García-Pérez, 2010). Agribusiness value chain is best to ascertain the level of commodity input and output flows within an economy (Faße, Grote \& Winter, 2009). Webber \& Labaste (2010) suggest that the value chain influences the parties involved either vertically or horizontally. Likewise, the consumer is vertically influenced, whereas the suppliers, farmers, wholesalers or even the community are influenced horizontally in the value chain. In Malaysia, Noordin (2018) informs that the crops are divided into cash crops and food crops, refer Table 3.

Table 3: Types of crops in Malaysia

\begin{tabular}{|l|l|}
\hline \multicolumn{1}{|c|}{ Type } & \multicolumn{1}{c|}{ Example } \\
\hline Cash crops - plantation production & Rubber, cocoa, palm oil \\
\hline Food crops - foods production & Rice, vegetables, fruits \\
\hline
\end{tabular}

The development of agribusiness in Malaysia is dictated by the National Agriculture Policy (NAP 1-3) and continued with the National Agrofood Policy (NAP 4). It is also one of the key focus in the Malaysia Plan (MP) which is 
Norfaridah Ali Azizan, Amirul Afif Muhamat, Sharifah Faigah Syed Alwi, Husniyati Ali, Mohamad Nizam Jaafar \& Nur Hidayah Jusoh

Agribusiness As the Solution for The Underutilized Waqf Lands: A Viewpoint from The Waqf Administrators

reviewed every five years. These plans have provided directions to the sector, however the planning is somewhat lacking in term of foresighting input when developing the plan because some of the gaps are widening such as the food crops.

Currently, the government, through the Ministry of Agriculture and Food Industries (MAFI) is focusing to increase the supply of foods production, particularly rice to ensure the food security needs in Malaysia can be achieved. This is consistent with Ramaloo, Siwar, Liong \& Isahak (2018) recommendation for urban agriculture development based on the Penang's case study. The current local production of rice for national consumption is $70 \%$ and the remaining is imported from other countries (Abd Mutalib, 2019; Rosmiza et al., 2015; Tey, 2010). Nevertheless, the national food self-sufficiency is should be at $80 \%$ (Hadi, 2019).

\section{RESEARCH METHOD}

It has been mentioned earlier that this article presents a focused discussion or an excerpt from a bigger study. Thus, only a few key informants that are highlighted in relation to the issue of discussed in this article. The qualitative method was employed and semi-structured interview sessions were held with the key informants (senior managers) from Islamic Religious Council of Selangor, Islamic Religious Council of Perak (MAIPk), Islamic Religious Council of Federal Territory, Northern Corridor Implementation Authority (NCIA) and Wakaf Selangor Incorporated or PWS.

\section{FINDINGS}

Some of the findings gathered in this study are consistent with previous studies which signify that the issues are still exist and continuous action must be taken to reduce the gap, at least, if to eliminate them are difficult.

\section{Shariah requirements}

In general, the use of waqf lands for agribusiness is permissible however for waqf khas, there are specific requirements that need to be adhered. Firstly, the intention of the endower must be executed, however, if the endower's wishes might be impossible to be executed at that time because there is no urgent need for it then the waqf lands can be developed for other beneficial activities which are deemed suitable by the waqf trustee.

Nevertheless, it cannot be perpetuity because the original intention of the endower remains and must be executed when possible. For instance, there is waqf land endowed for a mosque or cemetery but in that vicinity, such facilities are available. Therefore, the land can be used for agribusiness (subject to the State Islamic Religious Council approval) within the stipulated period. 
Islam is the official religion for federation of Malaysia and Muslims in Malaysia follow the Sunni's sect. In the context of religious madhhab or school of thought, the Shafie madhhab opinions are being preferred before referring to other interpretations in other Sunni's madhhab such as Hanafi, Maliki and Hanbali (Ahmad, 2017; Man, Ali, Abdullah, \& Ramli, 2009). This is being practiced when the fatwa or solution on certain issues are not suitable for Malaysia as per the Shafie's madhhab due to the social, culture or the current situation.

According to the Hanbali madhhab, the waqf lands can be istibdal if the idle lands can be used to bring benefits to the beneficiaries. I would say the Hanbali madhhab is more flexible. For instance, even though the waqf land is doing well, it can be istibdal if there is better plan that could give better benefits to the beneficiaries. (Key informant 1)

There is no objection from the Shariah perspective since the agribusiness activities are just for temporary and not permanent. (Key informant 2)

Importantly, to reiterate previous point, the waqf lands for agribusiness is subject to the time consideration because the original intention of endower is different. When the original needs (as per endower's intention) arises, then the lands must be used for it. Thus, when drafting the agreement to develop the waqf lands for agribusiness, the agreement must reflect the situation, for instance the type of crops must be crops that can produce yield in a short cycle, process or clearing and cleaning the waqf lands before and after the agreement starts etc.

\section{Financial constraints}

Almost many corporations or government agencies face limitation with regard to funding, however, the situation of PWS and MAIPk is more critical because these are institutions that are being established for charitable causes but operating and being treated like other commercial institutions. They are responsible to manage among others; waqf lands that the proceeds from the waqf lands will be distributed back to the Muslims communities such as to the local mosques, madrasa, NGOs and others. Therefore, it is clear that the institutions are selling and marketing the "charitable products" instead of commercial products.

Accordingly, this situation has limits the institutions from being aggressive to develop and grow the waqf lands. It can be easily understood that MAIPk and PWS do not have sufficient funds to plan and execute more economic activities for the waqf lands because every project requires commitment of human resource, overhead cost, land premium, legal and administrations etc. 
Norfaridah Ali Azizan, Amirul Afif Muhamat, Sharifah Faigah Syed Alwi, Husniyati Ali, Mohamad Nizam Jaafar \& Nur Hidayah Jusoh

Agribusiness As the Solution for The Underutilized Waqf Lands: A Viewpoint from The Waqf Administrators

Interviewer: Does the state government provides MAIPk some funds to manage the waqf land?

Key informant 3: No. We are self-funded.

\section{Expertise to develop the waqf lands for agribusiness}

PWS and MAIPk do not have in-house expertise to plan and develop the waqf lands for agribusiness because that is not their forte; and this is expected. Therefore, the institutions have to outsource the talents from other agencies or companies so that they will have a committee of experts to advise them before venturing into agribusiness.

I think, in terms of expertise, MAIS and PWS do not have enough expertise and that must be outsourced. However, even though we outsourced, the committee (representative from MAIS or PWS) must be in the committee or company to ensure the interest of the stakeholders is taken care. Especially the intention of the bequether. (Key informant 2)

In other words, consortium of panel of experts to advise the PWS or MAIPk is possible, and this study believes that many Muslims experts are willing to contribute to these agencies for the sake of Allah and recognition of their expertise in forms of letters of appointment and certificates. This will not cost a lot to PWS and MAIPk.

However, the concern is in term of the governance because it involves audit process which is a continuous process in any agency that practices good corporate governance, and the situation is more critical due to the involvement of external parties with PWS and MAIPk. The agency issue is inherent in this situation particularly if the conflict of interest arises when the appointed expert or advisor leaks the information to his or her confidante or business associate with regard to the development of the waqf lands.

Likewise, the appointed experts also need to consistently monitor the agribusiness projects to ensure the objectives are met - this is time consuming. The statement from another key informant, who is a senior manager oversees agribusiness activities in the Northern region under Northern Corridor Economic Region (NCER) authority advises as follows:

Agribusiness cannot afford a simple mistake because the period or cycle taken before the mistake becomes visible is too long. Therefore, for this sector, better replicate the successful model and implement it rather than trial and error. The trial and error should be done at the university or research center level such as MARDI. (Key informant 4) 
PLANNING MALAYSIA

Journal of the Malaysia Institute of Planners (2021)

\section{Proposed model}

The Waqf Trustee-Anchor Company-Community Farmers Model (see Diagram 3 ) is suggested to be adopted by the waqf trustee or the State Islamic Religious Council based on the findings gathered from this study (Ali Azizan, Muhamat, Syed Alwi, Ali \& Abdullah, 2021).

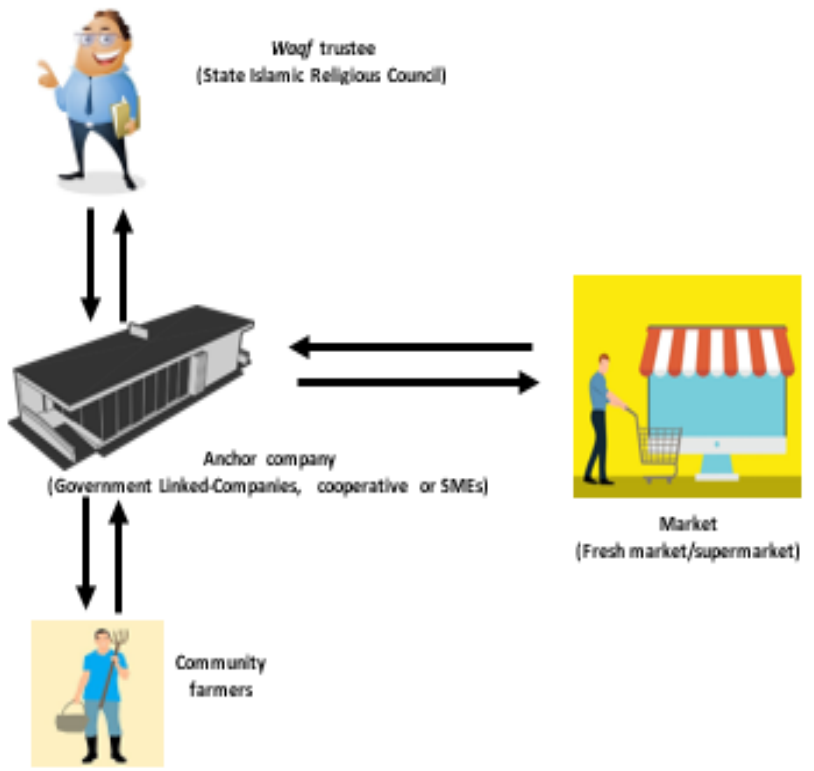

Figure 3: Waqf Trustee-Anchor Company-Community Farmers Model

A selection process must be developed to ensure the right anchor company is appointed for a particular agribusiness project. Amongst the criteria that should be included when assessing for anchor company is the financial capability, business plan, reputation and experience in agribusiness. The anchor company can be government linked-company (GLC), cooperative or small and medium enterprise (SME). A formal agreement should be signed between the trustee and the anchor company to ensure the responsibilities of each party are adhered and penalty if any party violates the terms.

In this model, it will include community farmers to join develop the waqf lands with the anchor company. This model is suitable if the waqf lands located far from the anchor company's location. By having the community farmers, the anchor company can nurture and train them to be successful entrepreneurs. In addition, it will save some costs for the anchor company because they do not have to monitor the activities daily.

The Waqf Trustee-Anchor Company-Community Farmers Model can be executed in the form of Islamic business model or contract such as profit- 
Norfaridah Ali Azizan, Amirul Afif Muhamat, Sharifah Faigah Syed Alwi, Husniyati Ali, Mohamad Nizam Jaafar \& Nur Hidayah Jusoh

Agribusiness As the Solution for The Underutilized Waqf Lands: A Viewpoint from The Waqf Administrators

sharing (musharakah) or profit and loss sharing (mudharabah) models. The musharakah or mudharabah models will offer higher return but begets higher risk (this is the consideration that the waqf trustee needs to consider in term of risk). The pertinent issue with agribusiness is the market place for the produce. Thus, this is the role of the anchor company that is not only to develop but also to market or sell the crops or livestock from the waqf lands.

\section{CONCLUSION}

This study informs that the issues or problems that were highlighted in previous studies are still exist, and they required immediate attention from the relevant stakeholders and authority to address them.

The waqf administrators or trustees do not against the use of waqf lands for agribusiness but as mentioned in the discussion, the agreement is important especially on the part of period to use the waqf lands for agribusiness because in general, it cannot be for a long time due to the endower's original intention on the land which is endowed.

The Waqf Trustee-Anchor Company-Community Farmer model is suggested based on the findings from this study. It can be executed in the form of Islamic business contract that surely will pave way financing from Islamic banks, that is compatible with the waqf institutions that is for the Muslims. Moreover, through this model, the rural farmers can be assisted so that they can have source of income and learn from the experienced and successful farmer - the anchor company. In addition, this study highlights the importance of urban planning and management on the waqf administrators and government agencies that because the waqf lands are scattered all over Malaysia, located in the urban and rural areas. Proper planning and modern farming technique will ensure the urbanisation process happen in order for the benefits of the waqf beneficiaries, endower as well as the community.

\section{ACKNOWLEDGEMENTS}

We would like to express our gratitude to the Ministry of Finance Malaysia and INSPEN for the NAPREC research grant 2019/2020, file no: 100-IRMI/GOV $16 / 6 / 2(019 / 2019)$ that has assisted us to complete this research.

\section{REFERENCES}

Abdul Karim, S. (2010). Contemporary shari'a compliance structuring for the development and management of waqf assets in Singapore. Kyoto Bulletin of Islamic Area Studies, 3(2), 143-164.

Abd Mutalib, Z. (2019). Ministry: rice production to be increased to 75 per cent, New Straits Times. 
Abu Bakar, N. A., Md Hussain, M. N., \& Hamed, A. B. (2017). Scrutinizing the effects of restructuring in Perbadanan Wakaf Selangor. International Journal of Accounting, 2(4), 13-21.

Abu Bakar, N. A., Md. Hussain, M. N., \& Hamed, A. B. (2017). Kaedah pembangunan tanah wakaf oleh Majlis Agama Islam dan Adat Melayu Perak (MAIPK). Journal of Islamic, Social, Economics and Development, 2(4), 2017.

Ali Azizan, N., Muhamat, A. A., Syed Alwi, S. F., Ali, H., \& Abdullah, A. Q. C. (2021). Revitalising Waqf (endowment) lands for agribusiness: potentials of the anchor company models. Journal of Agribusiness in Developing and Emerging Economies.

Azmi, A. S. M., Hanif, N. R., \& Mahamood, S. M. (2017). Revitalising the development of waqf properties: a way forward. International Journal of Real Estate Studies, 11(3), 1-11.

Behzadi, G., O'Sullivan, M. J., Olsen, T. L., \& Zhang, A. (2018). Agribusiness supply chain risk management: A review of quantitative decision models. Omega, 79, 2142.

Clay, P. M., \& Feeney, R. (2019). Analyzing agribusiness value chains: a literature review. International Food and Agribusiness Management Review, 22(1), 31-46.

Faße, A., Grote, U., \& Winter, E. (2009). Value chain analysis methodologies in the context of environment and trade research: Discussion papers//School of Economics and Management

Giraldo, O. F. (2019). Territorial control and geographical expansion of agribusiness Political Ecology of Agriculture (pp. 35-59): Springer.

Hadi, E. (2019). Food security in Malaysia: rice above all. Retrieved 20 September 2020, 2020, from https://www.emirresearch.com/food-security-in-malaysia-rice-aboveall/.

Ibrahim, A., \& Ibrahim, A. (2018). Pelaksanaan istibdal dan pembangunan tanah wakaf di Perak. Asian People Journal (APJ), 1(2), 287-297.

Ibrahim, T. A.-N. (1995). The Islamic personality (Vol. 2): Dar al-Ummah.

Ismail, C. Z., Salim, N. J., \& Hanafiah, N. J. A. (2015). Administration and management of waqf land in Malaysia: Issues and solutions. Mediterranean Journal of Social Sciences, 6(4), 613.

Kamarudin, K. (2019). Tanah wakaf boleh dimanfaatkan untuk kumpulan B40, Bernama.com. Retrieved from http://www.bernama.com/bm/news.php?id=1738830

Lewis, R. B. (2004). NVivo 2.0 and ATLAS. ti 5.0: A comparative review of two popular qualitative data-analysis programs. Field methods, 16(4), 439-464.

Mahamood, S. M., \& Ab Rahman, A. (2015). Financing universities through waqf, pious endowment: is it possible? Humanomics, 31(4), 430-453.

Muhamat, A. A., \& Jaafar, M. N. (2012). A study on the prospect of waqaf (endowment) lands for agricultural activities: an exploratory study on Kota Setar district, Kedah. Jurnal Pengurusan Awam, 9(1).

Man, S., Ali, A.K., Abdullah, L.H. and Ramli, R. (2009), "Kesesuaian pemikiran dan amalan mazhab selain Syafi'i dalam masyarakat Islam di Malaysia: satu analisis awal", Jurnal Fiqh, Vol. 6, pp. 21-40. 
Norfaridah Ali Azizan, Amirul Afif Muhamat, Sharifah Faigah Syed Alwi, Husniyati Ali, Mohamad Nizam Jaafar \& Nur Hidayah Jusoh

Agribusiness As the Solution for The Underutilized Waqf Lands: A Viewpoint from The Waqf Administrators

Noordin, K.A. (2018), "Agriculture: addressing food security in Malaysia”, The Edge.

Ramaloo, P., Siwar, C., Liong, C. Y., \& Isahak, A. (2018). Identification of strategies for urban agriculture development: A SWOT analysis. Planning Malaysia, 16(7).

Rashid, K. A., Fauzi, P. N. F. N. M., \& Hasan, S. F. (2018). Meeting housing needs of the poor and needy Muslims through Zakat and Wakaf. Planning Malaysia, 16(7).

Rosmiza, M., Davies, W., Rosniza, A. C., Jabil, M., Mazdi, M., Toren, W. W., \& Rosmawati, C. C. (2015). Stagnation of rice straw agribusiness development in Malaysia: the entrepreneurs' perspectives. Mediterranean Journal of Social Sciences, 6(4), 523-523.

Webber, C., \& Labaste, P. (2010). Building competitiveness in Africa's agriculture. A guide to value chain concepts and applications. Washington DC: The World Bank.

Yanes-Estévez, V., Ramón Oreja-Rodríguez, J., \& García-Pérez, A. M. (2010). Perceived environmental uncertainty in the agrifood supply chain. British Food Journal, 112(7), 688-709.

Received: $12^{\text {th }}$ July 2021 . Accepted: $17^{\text {th }}$ Sept 2021 